\title{
Når krisa rammer - på arbeidsplassen
}

\author{
Rolf U tgård intervjues av N ora Blaasvær.
}

\begin{abstract}
Et menneske tar sitt liv. En hel sivilisasjon berøres. En liten eller stor sivilisasjon av mennesker som kjente den som valgte å auslutte sitt liv. Etterlatte i naer krets - familie og venner, arbeidskollegaer og skolekamerater, nabolag, behandlere, frisør ... Denne artikkelen er skrevet med utgangspunkt i mennesker som tilhører den sivilisasjonen rundt et menneske som vi kaller arbeidsplassen. De fleste av oss tilhører en arbeidsplass, - et sted vi tilbringer mye av vår tid, et miljø vi investerer av oss selv i, med mennesker som kjenner oss og følger oss gjennom en periode i livet. I hvilken grad har arbeidsgiver og arbeidskollegaer ansvar for - og mulighet for å gripe inn i et menneskes liv - og i den suicidales liv?
\end{abstract}

\section{Arbeidets verdi}

Rolf U tgård er konserntillitsval gt i A ker K værner. Vi kjenner ham som ansiktet utad for alle de 35.000 ansatte i A ker K værner som sist høst kjempet en innbitt kamp for sine arbeidsplasser. U tgård er på mange måter blitt personifiseringen av arbeidstakerens sårbarhet i samfunnet. $\mathrm{H}$ va skjer når en arbeidsplass trues - og hva kan skje i et menneske som opplever å bli sagt opp ? O g hvordan forholder arbeidsplassen som sivilisasjon seg til det at oppsigel ser kan utløse svært alvorlig krise i et menneskes liv ? R olf $U$ tgård tror på samfunnets ansvar i møte med individet, han tror på vårt alles ansvar overfor hverandre - men fremholder også den enkeltes ansvar for eget liv. Selv har han i flere kritiske nedbemanningsprosesser opplevd slike situasjoner og i hvert fall én gang at koll egaer har tatt sitt liv.

\section{H va betyr arbeid for et menneske ?}

- A rbeidet er en av menneskets viktigste sosiale aktiviteter. G jennom arbeidet får man sosial bekreftelse, og gjennom stillingen man innehar får man bekreftet sin verdi, en tilhørighet og sin posisjon i samfunnet og i en sosial sammenheng. $\AA$ motta anerkjennelse for arbeidsinnsats fra sine kollegaer, sin sjef eller sine underordnede betyr enormt mye, sier R olf $U$ tgård. $\mathrm{H}$ an underkjenner ikke andre arenaer som viktige for å bekrefte et menneske - og snakker varmt om behovet for et nettverk av venner, familie og annen sosial aktivitet, men for de aller fleste av oss er arbeidet den viktigste arenaen.

- Ja, kan hende en for viktig arena, sier han når jeg spør om vi kanskje gir jobben for stor plass i livene våre.

- Særlig i vår tid da det å ha mye å gjøre og det à gi alt på jobben, lett gjør oss mindre involvert $i$ arenaer utenfor jobb og gir oss mindre nærhet til menneskene som kjenner oss privat. Det er sårbart og kan gjøre fallhøyden for stor dersom bekreftelsen fra arbeidsgiver uteblir.

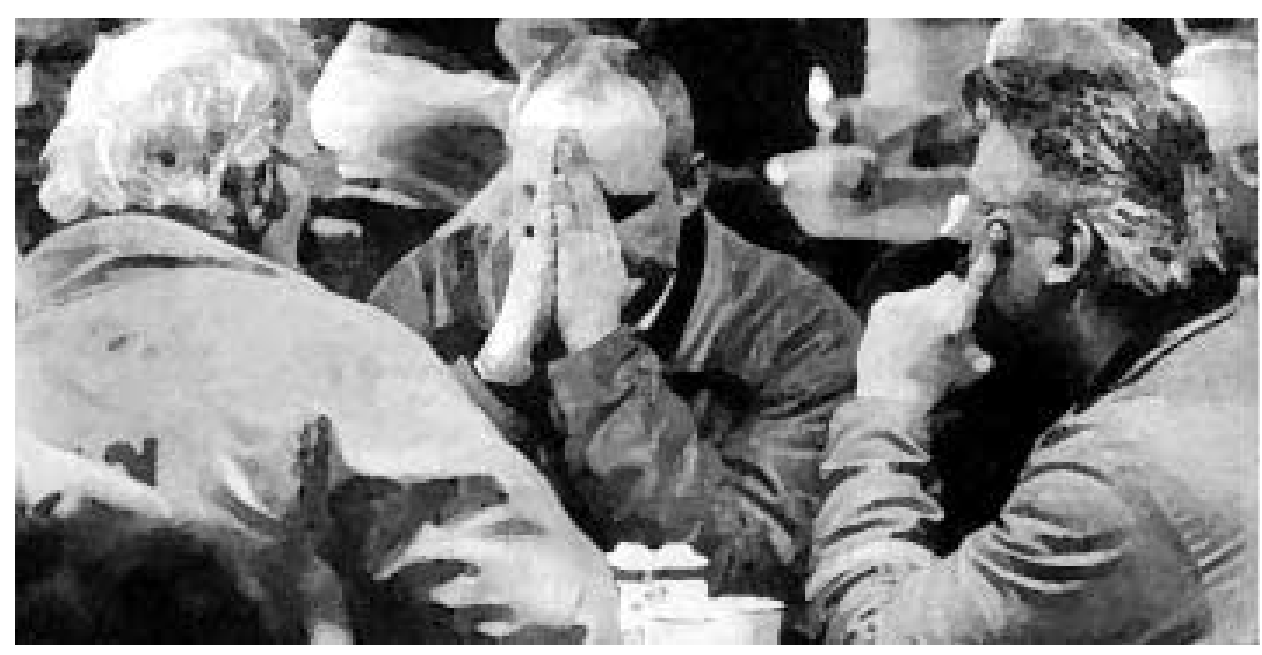

Kan man forvente at en arbeidsgiver også er opptatt av den personlige belastningen en oppsigelse kan være for en arbeidstaker?

- En arbeidsgiver skal være opptatt av dette. Både med utgangspunkt i en bedriftsøkonomisk tenkning og på bakgrunn av medmenneskelig ansvar, sier U tgård, og begrunner dette med at en nedtrykt medarbeider betyr lav effektivitet for en bedrift. En medarbeider som møter veggen bidrar lite til fellesskapet, mens en medarbeider som blir sett og blir fulgt opp i en krisesituasjon, igjen kan forventes å bidra i bedriftens arbeid.

$M$ en med sin sterke fagforeningshistorie er det liten tvil om at U tgård setter sin lit til arbeidskollegaer mer enn bedriftsledelse hva gjelder oppfølging av den enkelte i krisesituasjoner. $\mathrm{H}$ er trer lojaliteten og kameratskapet inn, man slår ring rundt en truet kollega, en arbeidsgiver får - $\mathrm{i}$ vår arbeidssammenheng i verkstedsindustrien - aldri lov til å "ta" en arbeidstaker. H er gjelder lojaliteten - og når en bedrift ønsker å "rydde unna" in effektiv arbeidskraft samtidig som man gjennomgår en nedbemanningsprosess - rett og slett for å slå to fluer $\mathrm{i}$ en smekk for bedriften, da trer fagforeningens rettferdighetsprinsipper inn. Det er ikke slik at de svakeste nødven- digvis skal gå i en nedbemanning - det må gjelde prinsi pper som er kollektive, slike som ansiennitet. Ellers blir det for personlig og umenneskelig, sier U tgård.

\section{Når krisa rammer}

$H$ an forteller om hvordan fagforeningen i K værner gang på gang har jobbet seg gjennom lister over ansatte ledel sen ønsker à kvitte seg med $\mathrm{i}$ en nedbemanning, og hvordan man da har forsvart ansienniteten. Fagforeningen har i slike situasjoner tatt ut mennesker som trenger beskyttelse og som de vet ville oppleve en stor personlig knekk ved en oppsigelse. En oppsigel se må skje etter verdige og formelle kriterier - og dette er det arbeidsgivers ansvar å sørge for. Er det en arbeidstaker som ikke gjør jobben sin godt nok, skal han selvfølgelig måtte stå til ansvar for det - men dette er det ledelsens jobb å ta underveis - ikke som en del av en annen prosess fordi det sparer en for ubehageligheter. I forbindelse med en nedbemanningsprosess må man velge andre kriterier enn de personlige. A nsiennitet forteller ikke noe annet enn at man var for ung eller hadde kort tid i bedriften. M en her er det mang en ledelse som svikter, sukker U tgård, og kommer inn på det som er hans kjernepunkt - nemlig kjennskapet til medarbeiderne. 


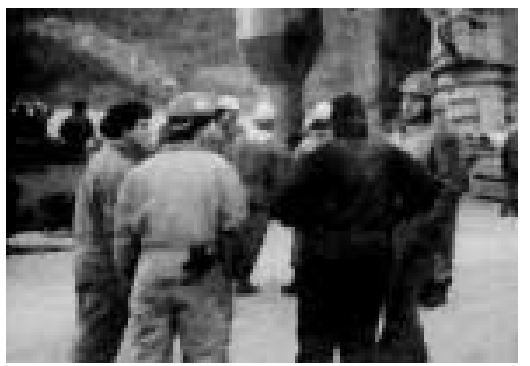

- En arbeidsgiver har juridisk ansvar for at det er et godt psykososialt miljø på arbeidsplassen, men forebygging krever langt mer. Det krever en forståelse for og en strategi for hvordan man tar vare på folk i bedriften. Klubben kjenner sine medarbeidere og i dette ligger mye forebygging av kriser. Etter lang tid ved siden av hverandre i en krevende arbeidshverdag, etter å ha svetta sammen, dusja sammen, spilt fotball sammen og drukket øl sammen, kjenner vi hverandre godt og vi kan hverandres historie. D ette gjør fagforeningens rolle som mediator mellom bedriftsledel se og ansatt særdeles viktig, fordi vi kan snakke med den enkelte utifra den enkeltes behov. Dette er viktig i møte med mennesker hvor vi vet at en oppsigelse vil føre til følelsen av tapt verdi, selvfølelse og opplevelsen av at alt rakner. Dette handler jo i bunn og grunn om samtale, sier U tgård, som savner ledere som kan snakke med sine ansatte. Det å få en skikkelig forklaring på situasjonen, bli spurt om hva dette betyr for deg og det å få litt tid på seg til å venne seg til tanken, er avgjørende for hvordan medarbeideren takler oppsigelsen. M en U tgård viser til graverende eksempler på hvordan ledere legger oppsigelsesbrevet på pulten om kvelden slik at det ligger der som en bombe når medarbeider kommer på jobb om morgenen, hvordan bedriftsledelsen ønsker tempo og trøkk i en nedbemanning, mens tid og tilvenning er behovene hos de ansatte. - Det er klart det går galt en gang i blant, sier U tgård som altså selv har mistet kollegaer i selvmord.

\section{Så hva skjer da på arbeidsplassen når dette verst tenkelige inntreffer - og hva har dere som fagforening gjort for å forebygge at dette skal skje igjen ?}

- Ethvert menneske har ansvar for sitt eget liv og også for sin jobb. M an har valgt à inngå en arbeidskontrakt og skal utføre arbeid mot betaling. M en så har vi også organisert oss i et samfunn, som preges av relasjoner og som er basert på at man tar ansvar for hverandre i en del situasjoner. I et samfunn forventer man at alle tar ansvar for seg - men man håper samtidig at folk også tar ansvar for hverandre. Det er her kollegaene kommer inn, klubben som har funnet sin måte å organisere dette samfunnsansvaret på slik at man ivaretar den enkelte. Vi har folk som har til opp- gave å gripe inn når man ser tegn på at en kollega har det vanskelig. Vi forsøker å organisere oss slik at vi skal gripe inn i hverandres liv innimellom. Det kan være tegn som økt sykefravær, stadig mer overtid, men likevel lite produktivitet - som er et tydelig tegn på at man ser i veggen og ikke kommer i gang. Eller det kan være $ø$ kt alkoholforbruk, eller rett og slett at den ansatte trekker seg stadig mer inn i seg selv. Slike signaler skal ikke forekomme lenge i våre sammenhenger før en ansatt med en faglig rolle og autoritet skal gripe inn og invitere til samtale knyttet til det man har observert. V åre tillitsval gte skal tørre å si i fra og komme i dialog. V år erfaring er at dette kan snu folk som er på vei inn i en krise - det å bli sett og ikke overlatt til seg selv, gir nytt mot, sier U tgård. Som stort sett beveger seg i mannsmiljøer hvor "den gode samtalen" ikke er det dominerende.

- N ei, det er vel mer som lekende løver, som knurrer og skumper borti hverandre, sier U tgård, og gir meg et dunk i skuldra som kan være et uttrykk for kameratskap og nærhet.

- Vi kan ikke påta oss eller pålegge noen i vår arbeidssammenheng å være sosial kurator, men vi har et ansvar for å konfrontere folk med det vanskelige tidlig, slik at det ikke får utvikle seg til noe kritisk. $0 \mathrm{~g}$ det er jo ingen tvil om at et menneske som fungerer dårlig på jobb er en belastning for alle - så her er det vinning i å forebygge for alle parter, sier U tgård - som dermed viser at han ikke kun er opptatt av den ansattes situasjon, men også av bedriftens beste.

\section{Vi som var rundt}

I en av nedbemanningsprosessene i A ker K værner, tok to ansatte sitt liv etter oppsigelse. Som tillitsval gt blir disse spørsmålene påtrengen de og overvel dende: Kunne vi løst dette annerledes ? Var prinsippene vi godtok for nedbemanning riktige? Fulgte vi opp den enkelte godt nok? En alvorlig U tgård erkjenner i ettertid at de i denne konkrete situasjonen ikke kjente de to godt nok.

- H adde vi visst mer om deres personlige historie og lynne, kunne vi kanskje gått inn og skjermet, sier han, og opplever at hans viktigste erfaring etter denne historien er at de som skal drive en slik kritisk prosess i en bedrift, må kjenne medarbeiderne. Eksterne konsulenter eller ledere som hentes inn til å gjøre en slik "ryddejobb", kan ikke bidra med det nødvendige kjennskap for å forebygge personlige kriser etterfølgende en oppsigelse. $\mathrm{M}$ an må bruke folk som kjenner medarbeiderne, ellers er innsatsen på det personlige plan verdiløs. Lojaliteten i en medarbeiderstab er etter U tgårds erfaring i aller størst grad knyttet til de andre kollegaene - ikke til bedriften og ledel sen. Innsats og motivert arbeidskraft kommer som en følge av en lojalitet og et samhold blant de som gjør jobben - og det er her det må mobiliseres dersom man skal arbeide forebyggende.

- Vi tillitsvalgte lever jo av samtalen og skal være gode på den, men i miljøet for ørig er det lite personlig prat og nærhet, sier U tgård - som altså gjerne ser en ytterligere styrking av lederens rolle i forhold til samtalen med de ansatte.

- En leder som kan snakke med sine medarbeidere er gull verdt, sier han - og oppfordrer bedriftsledelser til å utvikle kompetansen på samtale både blant de tillitsvalgte og i ledelsen selv. - Blant gutta jeg jobber med, ser jeg at mange har for fă de snakker med. Se bare hvilken funksjon frisøren eller fysioterapeuten făr for mange av oss, eksemplifiserer han og mener det er avgjørende at en bedrift, stor eller liten, institusjonaliserer ansvaret for samtalen og det å komme i dialog i vanskelige situasjoner. - Slikt kommer ikke av seg selv, sier han, og blir tydelig ettertenksom på i hvilken grad de selv nå har klart å åpne for samtalen rundt hva det gjør med de A ker K værneransatte å oppleve sin arbeidsplass truet i den grad den var det høsten 2001.

( $N$ ora Blaasvær er general sekretær i Kirkens SOS i N orge og redaksjonsmedlem i Suicidol ogi.)

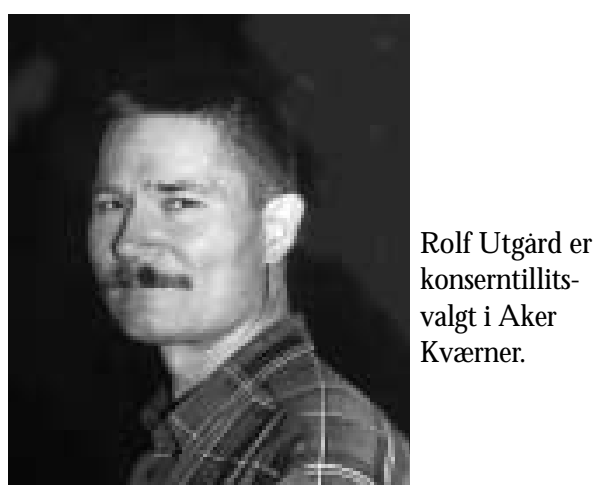

